\title{
The Effects of Low Dose Zinc Supplementation on the Development of New Bone in Rabbits
}

\author{
Tavşanlarda Düşük Doz Çinko Illavesinin Yeni Kemik Gelişimi Üzerine Etkisi \\ (1) Mustafa Çalık1, (1) Saniye Göknil Çalık², (1) Mustafa Dağ|ı , (1) Mustafa Cihat Avunduk4 \\ 1 University of Health Sciences Turkey, Konya Training and Research Hospital, Clinic of Thoracic Surgery, Konya, Turkey \\ ${ }^{2}$ Vocational School of Health Services KTO Karatay University, Emergency and First Aid Program, Konya, Turkey \\ 3University of Health Sciences Turkey, Konya Training and Research Hospital, Clinic of Cardiovascular Surgery, Konya, Turkey \\ ${ }^{4}$ Necmettin Erbakan University Meram Faculty of Medicine, Department of Pathology, Konya, Turkey
}

\begin{abstract}
Introduction: Zinc (Zn) is an essential element for the healthy bone metabolism. It promotes bone formation by stimulating the proliferation and differentiation of osteoblasts, and increases the stimulation of osteoblastic bone mineralisation. Also, it suppresses the differentiation of osteoclasts while inhibiting bone resorption. The purpose of this study is to investigate the effects of low-dose Zn supplementation on new bones grown in rabbits.
\end{abstract}

Methods: We evaluated 40 male white rabbits aged six weeks from New Zealand in 8 groups, with each including 5 subjects. All the groups underwent subperichondrial costal cartilage resections from the third rib on the right hemithorax. Rabbits in first and second groups underwent the partial resection of two ribs, and rabbits in third and fourth groups underwent total rib resection. Rabbits in fifth and sixth groups underwent the partial resection of four ribs, whereas rabbits in seventh and eighth groups underwent total resection. Rabbits in Groups 2, 4,6 , and 8 were treated with $6 \mathrm{mg} / \mathrm{kg} /$ day intraperitoneal $\mathrm{Zn}$ for four weeks after the operation. All groups were followed up to the $24^{\text {th }}$ week of their lives.

Results: We detected a statistically significant difference for both osteoblasts and osteoclasts among all the subgroups. Additionally, we also detected a significant increase in bone consolidation by Zn supplementation. Our study found that $\mathrm{Zn}$ suppresses osteoblastic bone absorption by stimulating osteoblastic bone formation in the light of the literature.

Conclusion: Low-dose $\mathrm{Zn}$ administration in rabbits has been found to expedite the rib consolidation. $\mathrm{Zn}$ can be used to increase the bone maturation such as at the site of new bone formation in rib fracture and after all kinds of operations related to bones.

Keywords: Zinc, rib fracture, bone development

\section{öZ}

Amaç: Çinko (Çn), sağııkı kemik metabolizmasında vazgeçilmez bir elementtir. Osteoblast proliferasyonunu ve farklılaşmasını uyararak kemik oluşumunu uyarır; osteoblastik kemik mineralizasyonunu artırır. Ayrıca, kemik emilimini inhibe ederken, osteoklastların farkılış̧masııı baskılar. Çalışmamızda düşük doz Çn desteğinin tavşanlarda yeni kemik gelișimi üzerindeki etkileri araștırıldı.

Yöntemler: Kırk erkek Yeni Zelanda beyaz tavşanı 6 haftalıkken, her biri beş denekten oluşan sekiz eșit grupta değerlendirildi. Tüm gruplara sağ hemitoraksta üçüncü kaburgadan itibaren subperikondriyal kostal kıkırdak rezeksiyonları yapıldı. Grup 1 ve 2'deki tavşanlara iki kaburgaya parsiyel rezeksiyon; 3. ve 4. gruptaki tavşanlara total kaburga rezeksiyonu, 5. ve 6 . gruptakilere dört kaburgaya parsiyel, 7. ve 8. gruptakilere ise total kaburga rezeksiyonu yapıldı. Grup 2., 4., 6., 8.'deki tavşanlara ameliyat sonrası dört hafta boyunca $6 \mathrm{mg} / \mathrm{kg} /$ gün intraperitoneal Çn uygulandı. Tüm gruplar, yaşamlarının yirmi dördüncü haftasına kadar takip edildiler.

Bulgular: Tüm alt gruplar arasında osteoblastlar ve osteoklastlar açısından istatistiksel olarak anlamlı fark saptandı. Çn takviyesi ile kemiğin konsolidasyonunda, önemli ölçüde artış görüldü. Çalıșmamızda Çn'nin osteoblastik kemik oluşumunu uyararak osteoklastik kemik emilimini baskıladığı literatür bilgileri eșliğinde tespit edildi.

Sonuç: Tavşanlarda düşük doz çn verilmesi kaburga konsolidasyonunu hızlandırmaktadır. Çn, kaburga kırı̆ıındaki gibi kemik oluşumunun yeri ve kemikle ilgili her türlü işlemden sonra kemik oluşumunu artırmak için kullanılabilir.

Anahtar Kelimeler: Çinko, kaburga kırı̆̆ı, kemik oluşumu

Cite this article as/Atıf: Çalık M, Göknil Çalık S, Dağlı M, Avunduk MC. The Effects of Low Dose Zinc

Supplementation on the Development of New Bone in Rabbits. İstanbul Med J 2020; 21(3): 190-5. 


\section{Introduction}

Hydroxyapatite crystals, which are the mineral structures of bone, contain many trace elements such as magnesium (Mg), fluorine (F), manganese, zinc (Zn), silicon (Si) and strontium, thus representing only a small part of the bone mass. Zn, which was first described in 1941, is indispensable in the bone metabolism of humans and animals (1-3). Zn promotes bone formation by stimulating the proliferation and differentiation of osteoblasts, and increases the stimulation of osteoblastic bone mineralisation via alkaline phosphatase activity and collagen synthesis. Also, it suppresses the differentiation of osteoclasts while inhibiting bone resorption (4). The purpose of this study is to investigate the effects of low-dose Zn supplementation on the development of new bones in rabbits.

\section{Methods}

We conducted this experimental study at the Experimental Medicine and Research Centre of local University. We randomly evaluated a total of same-generation 40 male white rabbits aged 6 weeks from New Zealand evaluated in 8 groups, with each of them including 5 subjects. All animals received human care and were utilised in compliance with the standards established by the European Convention for Animal Care and Use of Laboratory Animals. The rabbits were fed with a standard pelleted diet and were allowed to access tap water ad libitum. The animals were housed in the standard individual cages on a 12-h light/dark cycles at room temperature in a humidity-controlled environment. The local Animal Ethics Committee of Selçuk University approved all the studyrelated procedures (2011/075). This study was certificated and funded by the School of Medicine Animal Care and Investigational Committee at our institution. Funding providers do not have any contribution or influence in the design, data collection, analysis, publication decision or preparation of the article.

\section{Study Design}

\section{Groups}

In total, 40 male white rabbits aged six weeks from New Zealand were evaluated in 8 groups, with each of them including 5 subjects. Before the operation, the rabbits were numbered, and their weights were noted in grams. The entire process was performed under general anaesthesia with sterile conditions. Subperichondrial rib resections starting from the third costal cartilage were carried out in the right hemithorax. The partial resection of two ribs was performed in the rabbits of first and second groups, whereas total resection was carried out in the rabbits of third and fourth groups. Rabbits in fifth and sixth groups underwent partial resection of four ribs, and rabbits in seventh and eighth groups underwent complete resection of ribs. Costochondral joints were saved in partial resections and removed in total resections. Three-quarters of the costal cartilages were removed in the partial resections.

\section{Anaesthesia}

Ketamine $\mathrm{HCl}$-induced general anaesthesia (Ketanest, Pfizer Pharma $\mathrm{GmbH}$, Karlsruhe, Germany) in the quantity of $15-20 \mathrm{mg} / \mathrm{kg}$ i.v. or 20$25 \mathrm{mg} / \mathrm{kg}$ i.m. was used in our study. It was maintained by Xylazine (Alfazyne 2\%; Alfasan International. BV, Woerden, the Netherlands) 0.5-1 $\mathrm{mg} / \mathrm{kg}$ i.v. or $1-2 \mathrm{mg} / \mathrm{kg}$ i.m. If needed, same dosages of Ketamine $\mathrm{HCl}$ and Xylazine were repeated with reflex responses (pedal reflex, palpebral and corneal reflexes) to keep the constant depth of anaesthesia. Body temperature was monitored by inserting a heat probe into the ECG and rectum with the aid of needle electrodes. The heating lamps were used to keep the animals at a body temperature of $37 \pm 5^{\circ} \mathrm{C}$ during the surgical preparation and working period. The mean anaesthesia time was 12-15 min for each rabbit. No animals were treated with any local and systemic antibiotics.

\section{Operation Technique}

The subjects were placed in right lateral decubitus position on the operating table where they were breathing spontaneously. Then, their chests were shaved and cleaned with a povidone-iodine solution (10\% povidone-iodine, Betadine, Kansuk, İstanbul, Turkey). Median sternotomy incision was made after infiltration with 1\% lidocaine and 1:100,000 epinephrine (Jetokain Simplex ampule; Adeka Pharmaceutical Company, İstanbul, Turkey). The pectoral muscles were divided along the lateral side to allow the exposure to costal cartilages and thoracic wall (Figure 1). Subperichondrial costal cartilage resections beginning from the third costal cartilage were performed in the right hemithorax according to the respective groups (Figure 2A, 2B, 3A). In each subject, bleeding and pneumothorax control were performed with sterile serum saline (Figure 3B). After all checks, the chest wall was closed with continuous sutures by anatomical layers without any grafting.

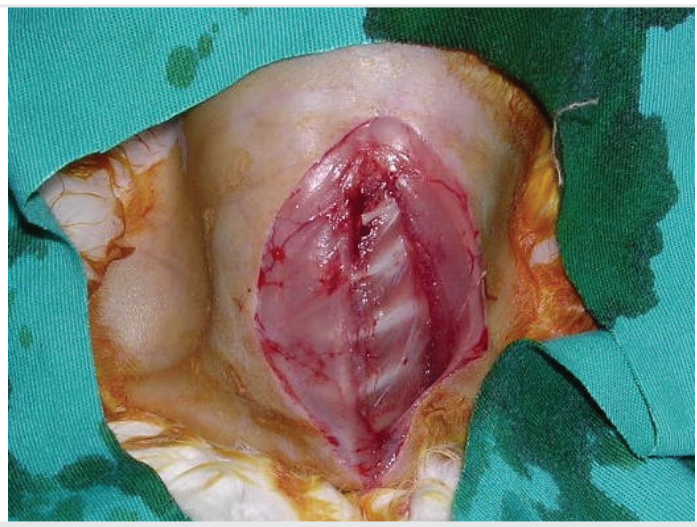

Figure 1. Median sternotomy incision was made, and the chest muscles were laterally divided to reveal the costal cartilage

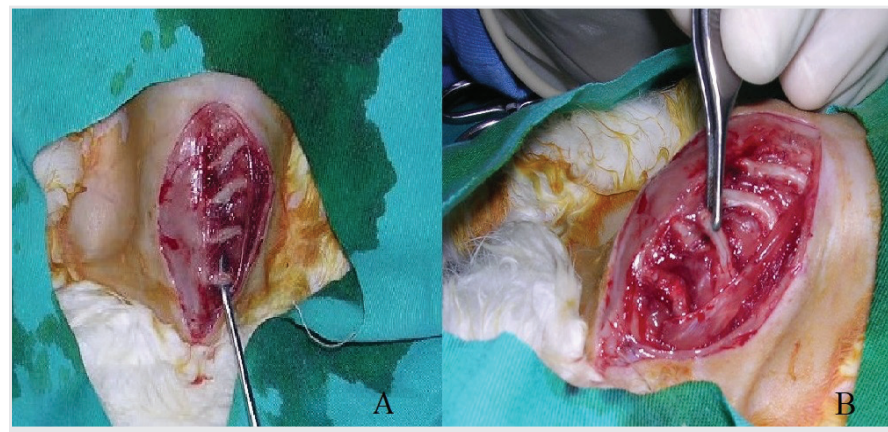

Figure 2. Costal resections starting from the (A) third and (B) fourth costal cartilages were performed in the right hemithorax according to the respective groups 


\section{Postoperative Care and Follow-up}

Pain control in animals was accomplished by Tradomol $\mathrm{HCl}$ (Contramal, $100 \mathrm{mg} 2 \mathrm{~mL}$, Abdi İbrahim Ltd., İstanbul, Turkey) in the quantity of 1-2 $\mathrm{mg} / \mathrm{kg} /$ day i.m. for five days during the postoperative period. The animals were followed-up till the rabbits were accepted to enter adulthood at the $24^{\text {th }}$ week of their lives. All the animals were euthanised with a lethal IV dose of non-barbiturate anaesthetic (Ketamine/Xylazine) painlessly according to the existing instructions established by the latest report of the AVMA Panel on Euthanasia. Three times the anaesthetic dose was used for euthanasia (5).

\section{Zinc Protocol}

The specified amount of zinc sulphate ( $\mathrm{ZnSO}_{4}$ ) (Merck, CAS No. 7446-20-0 Darmstadt, Germany) was dissolved in the distilled water. The injected solution was prepared by diluting the stock solutions on a daily basis. The working solution was used within one hour after the preparation. $\mathrm{Zn}$ was administered with $0.5 \mathrm{~mL}$ of saline by the intraperitoneal injection of $6 \mathrm{mg} / \mathrm{kg} /$ day at 10-12 times every day for 4 weeks after the surgery for groups 2, 4, 6 and 8 (6).

\section{Pathological Evaluation}

All the materials were decalcified in 10\% buffered formaldehyde for 48 hours after the fixation period until they were tempered enough to be cut with a microtome. Tissue specimens from appropriate sites were then acquired for the autotecnicon follow-up. These specimens were embedded in paraffin, stained with haematoxylin and eosin (H\&E), and sectioned with a microtome to calculate the osteoclasts, osteoblasts, lymphocyte count and the area of new bone formation (Figure 4). All the stained preparations were examined with Nikon Eclipse E400 light microscope (Nikon Corporation. Minatoku, Tokyo, Japan). Extreme care was exercised to select the same areas as much as possible for each case in evaluation. The chosen regions were scanned with a Nikon Coolpix 5000 digital camera (Nikon Corporation. Minatoku, Tokyo, Japan) with a microscope mounted at the same magnification. At the same time, images were also obtained for calibration with the same magnification of microscope (Nikon Stage Micrometer (MBM11100, Nikon Corporation. Minatoku, Tokyo, Japan). All images were transferred to a PC environment for analyses with Clemex Vision Lite 3.5 (Clemex Technologies Inc. Longueuil, Quebec Canada) (Figure 5). First, the length was calibrated with Nikon Stage Micrometer (MBM11100, Nikon

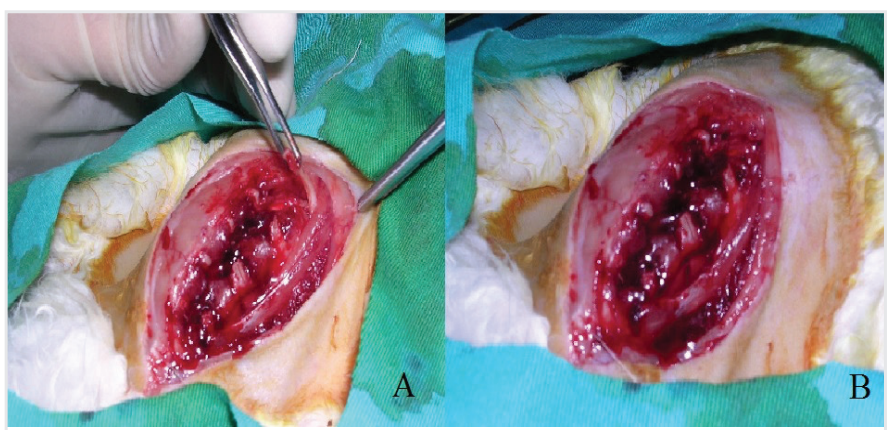

Figure 3. Costal resections of (A) the sixth cartilage were carried out in the right hemithorax according to the respective groups. Bleeding and pneumothorax control were performed with (B) sterile serum saline
Corporation. Minatoku, Tokyo Japan). After the calibration, the area to be examined was determined as $38,732.7 \mu \mathrm{m}^{2}$. The osteoblasts, osteoclasts and lymphocytes on the regions of $38,732.7 \mu \mathrm{m}^{2}$ selected on the digital images of H\&E-stained preparations were marked and automatically counted by the mentioned image analysis programme. The damaged cells were excluded from the evaluation during the examination.

\section{Statistical Analysis}

We assessed all the data by using the Statistical Package for Social Sciences (SPSS) 18.0 portable software for Windows (SPSS Inc, Chicago, Illinois, USA). In every subgroup, we analysed the histologic changes in the bone. Additionally, we evaluated the effect of Zn treatment among the groups by using Kruskal-Wallis test and Mann-Whitney $U$ test. There were statistically significant differences for osteoblasts and osteoclasts among all the subgroups (Table 1$)$. A p-value $(<0.05)$ was used to indicate a significant difference.

\section{Results}

Regardless of the cause of deaths, animals were replaced with the new ones. All rabbits included in our experiment lived up to the end of the

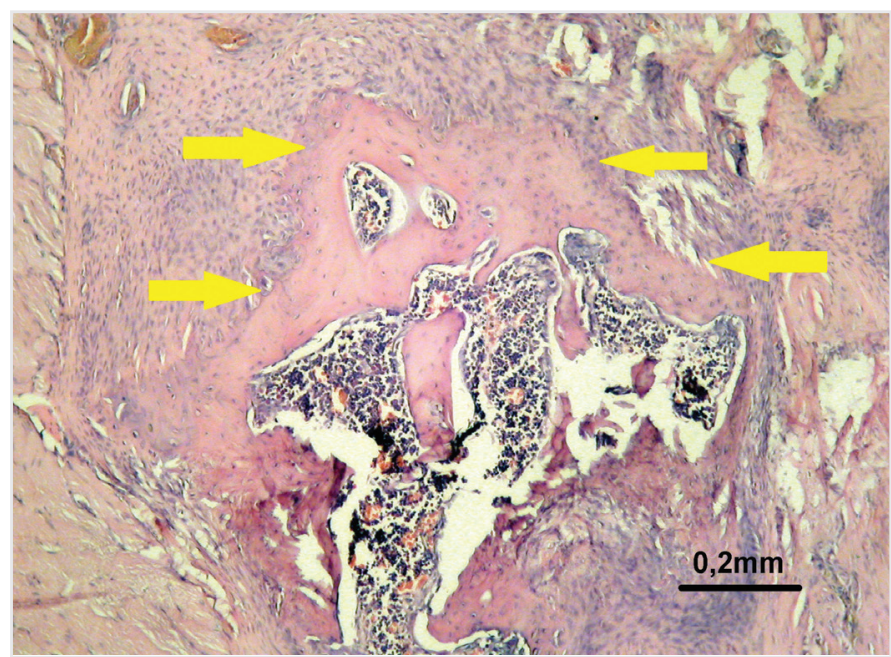

Figure 4. New bone formation areas are shown with yellow arrows (H\&E: $0.2 \mathrm{~mm}$ )

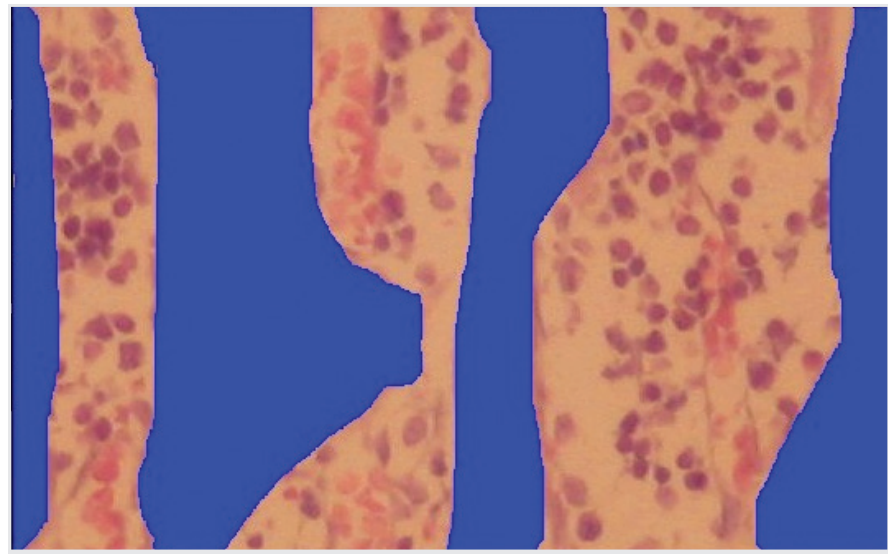

Figure 5. Calculation of new bone formation (NBF) area in a PC environment with Clemex Vision Lite 3.5 analysis programme (Clemex Technologies, Longueuil, Quebec, Canada) 
study. There were no local complications such as skin reaction, wound infections or bleeding around the operated sites. There were statistically significant differences for osteoblasts and osteoclasts among all the subgroups (Table 1).

Table 1 shows that there is no statistically significant difference among the groups in vascular endothelial growth factor (VEGF), lymphocytes and fibroblasts, except for first and second groups when these groups are compared as the groups with and without $\mathrm{Zn}$ administration. A significant difference in osteoblasts, osteoclasts and fibroblasts was only found between first and second groups. Table 2 shows the mean and standard deviation values of all the groups.

Although there is no difference in VEGF among the groups, the difference is higher in Zn-administered groups (group 2, 4, 6 and 8) than the groups without $\mathrm{Zn}$ administration (group 1, 3, 5 and 7). These groups were not affected by the size, number and shape of the surgical dissection.

There was no significant difference among the groups in lymphocytes. However, the number of lymphocytes is higher in Zn-administered groups than groups without $\mathrm{Zn}$ administration. $\mathrm{Zn}$ administration increased the number of lymphocytes. Besides, the number of lymphocytes was not affected by the size of the surgical dissection, the amount of resected ribs, and whether the costochondral junction, which is the growth centre, was resected. When the number of resected bones increases, and the growth centre is resected, more lymphocytes enter the fracture site.

Similar to lymphocytes, there is no significant difference in fibroblasts among the groups except for first and second groups. In the group without Zn, it was $5.8 \pm 1.30$ (as mean and standard deviation values) and $11.4 \pm 1.34$ in the group without $Z n$ administration. There is a significant difference only between these groups. We think that the limited resection and protection of the growth centre are the reasons for this difference. Although there was a removal of same number of ribs, there was no statistically significant difference between third and fourth groups in which the growth centre was not conserved and the mean. Standard deviation values were higher. Whether the growth centre is preserved or not, fibroblasts increased in all the groups when the four rib resections were performed. There were more fibroblasts in each group with $\mathrm{Zn}$ administration than the group without $\mathrm{Zn}$ administration.

Osteoblasts were also statistically significantly higher in each group with $\mathrm{Zn}$ administration than the group without $\mathrm{Zn}$ administration. However, they were lower in the groups (group 3, 4, 7 and 8) where the growth centre was resected than in groups than in the groups (1, 2, 5 and 6) where the growth centre was not resected. Even the positive effect of $\mathrm{Zn}$ did not prevent this decline.

Osteoclasts were statistically significant and lower in groups with $\mathrm{Zn}$ administration than the groups without $\mathrm{Zn}$ administration. However, in the groups in which the growth centre was resected (groups 3, 4, 7 and 8), osteoclasts were more than the groups without resection (groups 1, 2, 5 and 6). $\mathrm{Zn}$ decreases osteoclasts and increases the bone mass. It decreases osteoclasts, thus increasing bone mass and consolidation. Consolidation was significantly increased by $\mathrm{Zn}$ supplementation. According to the literature, in our study, Zn stimulates osteoblastic bone formation and suppresses osteoclastic bone resorption.

\section{Discussion}

Despite everything performed to reduce accidents, even today, there are about 5.8 million deaths related to trauma in hospitals worldwide. This figure is only considered for hospitals, and when out-of-hospital deaths are considered, the actual number is naturally higher than this value. Chest trauma is the third most common cause of death following abdominal and head trauma in patients with trauma (7). The incidence of chest trauma accounts for $10-15 \%$ of all traumas, and $85 \%$ of which have respiratory failure (RF). The mortality rate of chest trauma is between 5.7 and $12 \%$. When the other organ and system injuries are excluded, the mortality rate decreases by $1.1-2.4 \%$ (8). Traffic accidents,

Table 1. Comparative groups $t$ and $p$ values

\begin{tabular}{|c|c|c|c|c|c|c|c|c|}
\hline & \multicolumn{2}{|c|}{ Groups 1-2 } & \multicolumn{2}{|c|}{ Groups 3-4 } & \multicolumn{2}{|c|}{ Groups 5-6 } & \multicolumn{2}{|c|}{ Groups 7-8 } \\
\hline & $t$ & $p$ & $\mathrm{t}$ & $p$ & $\mathrm{t}$ & $p$ & $t$ & $p$ \\
\hline VEGF & -1.633 & 0.141 & -0.232 & 0.822 & -1.265 & 0.242 & -0.756 & 0.471 \\
\hline Fibroblasts & -6.693 & 0.000 & -0.061 & 0.953 & -0.279 & 0.788 & -0.316 & 0.760 \\
\hline Osteoblast & -4.788 & 0.001 & -5.200 & 0.001 & -5.949 & 0.000 & -6.128 & 0.000 \\
\hline
\end{tabular}

Table 2. The mean and standard deviation of the eight groups of the rabbits measured at 24 weeks of age ( $n=5$ for each group)

\begin{tabular}{|c|c|c|c|c|c|c|c|c|}
\hline & Group 1 & Group 2 & Group 3 & Group 4 & Group 5 & Group 6 & Group 7 & Group 8 \\
\hline VEGF & $4.8 \pm 1.48$ & $6.0 \pm 0.70$ & $6.0 \pm 1.22$ & $6.2 \pm 1.48$ & $5.2 \pm 0.44$ & $5.6 \pm 0.54$ & $5.8 \pm 0.83$ & $6.2 \pm 0.83$ \\
\hline Lymphocytes & $6.4 \pm 2.96$ & $8.6 \pm 1.94$ & $10.6 \pm 3.20$ & $13.6 \pm 2.96$ & $16.8 \pm 4.91$ & $17.0 \pm 5.14$ & $18.0 \pm 4.89$ & $18.8 \pm 1.48$ \\
\hline Fibroblasts & $5.8 \pm 1.30$ & $11.4 \pm 1.34$ & $14.2 \pm 6.53$ & $14.4 \pm 3.36$ & $18.6 \pm 2.96$ & $19.0 \pm 1.22$ & $19.4 \pm 2.30$ & $19.8 \pm 1.64$ \\
\hline Osteoblasts & $18.8 \pm 2.28$ & $25.4 \pm 2.07$ & $13.6 \pm 1.34$ & $18.8 \pm 1.78$ & $19.2 \pm 2.28$ & $27.4 \pm 2.07$ & $14.4 \pm 1.14$ & $19.6 \pm 1.51$ \\
\hline Osteoclasts & $5.8 \pm 0.83$ & $4.0 \pm 0.70$ & $7.0 \pm 1.58$ & $5.2 \pm 0.44$ & $6.0 \pm 0.70$ & $4.8 \pm 0.83$ & $7.4 \pm 1.14$ & $5.8 \pm 0.83$ \\
\hline
\end{tabular}


the most frequent cause of hospitalisation and RF, are anticipated to increase by $65 \%$ until 2033 in the developing countries. For this reason, it seems inevitable that we will encounter more RF in the coming years (9).

Today, because of the increased high-resolution computerized tomography, the diagnosis of RF is increasingly becoming more accurate than before. Even small non-displaced linear RF and additional thoracic pathologies such as pneumothorax and haemothorax are also easily detected. Its clinical significance and its effect on comorbidities should be investigated in detail. In our opinion, although their clinical significance is limited or minimal, their comorbidities may contribute. Patients with RF need aggressive pain control, pulmonary toilet, adequate respiratory rehabilitation and rational fluid therapy to prevent the potentially delayed pulmonary complications (10). Pain perception is severe and longer for elderly and female patients. There are no clear and publicly accepted guidelines for the treatment of RFs. Inadequate acute pain treatment can cause long-term and chronic pain. The poor treatment of severe pain can lead to the development of chronic, obstructive neuropathic pain, thereby leading to anatomic and physiological changes in the neural tissue in response to repetitive stimuli known as neuroplasticity or poorly. Pain is a subjective feeling; therefore, the objective measurement of the levels is difficult. In particular, pain reduces the quality of life in the early period after injury. RF pain is caused by the fractured bone and injured muscle area and is spread to different areas, especially to the same dermatomal region (8). Chronic pain depends on the intercostal nerve damage or continuous stimulation of the displaced ribs. In predicting the complications, the specificity of three or more rib fractures increases from $59.1 \%$ to $95.5 \%$ in the same number of displaced RF. There is no determined time for improvement after the RF. The perception of healing and pain is different among individuals. They are strongly related to each other. In the literature, there is a significant pain duration extending from 2 to 24 months following RF (10).

Whitson et al. (11) showed that high mortality and morbidity were not associated with the number of RF in 35.467 disease series. However, they did not assess whether rib fractures worsened or exacerbated existing comorbidities or had any effect on the severity of the accompanying injuries. On the contrary, Jones et al. (12) identified five and more RFs as an independent cause of mortality in 98.836 disease series.

Mostly, there is no correlation between the number of RF and the level of pain. Although it was not statistically significant, Kerr-Valentic showed a current correlation. On the first day of trauma, the level of pain in patients with two RF was statistically significant and higher compared than the patient with one RF. However, there was no statistical difference on the $15^{\text {th }}$ day, and further in the $3^{\text {rd }}$ and $6^{\text {th }}$ months. Lateral RFs cause more pain than the anterior and posterior RFs. The authors attributed it to the fact that respiratory and body movements are affected more by the lateral RF. The association with age and RF, and morbidity and mortality was determined clearly in the literature. The pain level of the elderly on the $15^{\text {th }}$ day, in the $3^{\text {rd }}$ and $6^{\text {th }}$ months, was higher than that of the young people, and the difference was statistically significant.

The authors have stated that the bone's mineral density in the elderly is lower but higher in the young people. This condition is attributed to the faster recovery of the RF. The control and/or reduction of pain not only relieves the discomfort of RFs but can also prevent the occurrence of complications. Until now, the treatment was mostly conservative and less surgical, but there were still deficiencies. This deficiency can be compensated by accelerating healing or by increasing the mineral density (8). In our study, osteoblasts that increase healing and mineral density were more in each group with $\mathrm{Zn}$ administration than the groups without $\mathrm{Zn}$ administration. Osteoblasts were also affected by other factors such as growth centre and several rib fractures. Osteoblasts were lower in the groups in which the growth centre was less affected, that is, underwent total resection than the groups that underwent partial resection. The number of osteoblasts decreases with the increased number of RF. Even Zn could not stop this reduction. As far as we know, the reduction in the rise of osteoblasts with the increased RFs is shown for the first time in the English literature. VEGF, lymphocytes and fibroblasts increased even though there was no statistical difference among them. More blood vessels mean more cells and more scar tissues.

The last 60 years have witnessed extensive research on the factors that increase bone healing. It has been widely shown in animal experiments that augment osteogenesis. These experiments studied extreme fractures such as radius and femur bones (13). Histological examination revealed that osteoblasts, osteoclasts, chondrocytes and mesenchymal stem cells were responsible for the development and healing of new bones. Mortality and morbidity are reduced with the control of pain in chest traumas and especially in RFs. They are reduced by the provision of pain and bone stability (14).

Although $\mathrm{Zn}$ is 23 in the rare element in the terra, it is the only trace element with an essential structural or enzymatic function of the six enzyme classes. These enzymes are osteogenic enzymes (2). In many parts of medicine including cardiothoracic surgery, oral surgery and orthopaedics as well as controlled and guided bone growth based on the bone metabolism consisting of osteogenesis, bone modelling and bone remodelling (15). According to the significant effect on the bone formation by Zn, we hypothesised that median sternotomy and the oral surgery can be used to accelerate healing in the treatment of rib fractures. Our experimental model was similar to a rib fracture model, in addition to the resection of the growth centre of the ribs (16). A research work has suggested minimal cartilage resection and saving the growth centre of the ribs at the costochondral junctions to produce faster healing (17). Nevertheless, histologic consolidation was significantly increased by Zn supplementation even in the group in which the growth centre was resected (Table 2). According to the literature, in our study, Zn stimulates osteoblastic bone formation and suppresses osteoclastic bone resorption.

Of course, just like every study, there are limitations to our study too. The studies conducted animals cannot entirely apply to humans. All of our subjects were homogeneous regarding race, generation, gender, diet and body weight. People are heterogeneous about gender, race, eating habits, body weight and accompanying diseases. Especially the method of administration, dose and additional costs of the $\mathrm{Zn}$ to be added to treatment should be investigated in humans. 


\section{Conclusion}

Although pain and healing are associated with each other, pain may be longer than the healing process. Pain may be related to nutrition, lifestyle and body mass index. It is challenging to optimise them for all patients while providing a standard lifestyle. Because of the severity, complexity and differences of RFs, it is a challenging subject for clinicians. Hence, better health care approaches are needed to reduce morbidity and mortality rates. However, different studies in patients with chest injuries have shown significant differences in morbidity and mortality; therefore, further research is needed to improve medical care. Our findings indicate that low-dose Zn supplementation accelerates the consolidation of ribs. $\mathrm{Zn}$ can be used to increase the bone maturation such as the site of new bone formation in rib fracture and after all kinds of operations related to bone.

Acknowledgment: We are grateful to the Emergency Physician Specialist, Assist. Prof. Zerrin Defne Dundar M.D. from the Department of Emergency Medicine, for her contribution and assistance in the evaluation of statistical analysis.

\section{Ethics}

Ethics Committee Approval: The Animal Ethics Committee of Selçuk University approved all the study-related procedures (2011/075). This study was certificated and funded by the School of Medicine Animal Care and Investigational Committee at our institution.

Informed Consent: This study is an animal experiment.

Peer-review: Externally peer-reviewed.

Authorship Contributions: Surgical and Medical Practices - M.C,., S.G.C.., M.D., M.C.A.; Concept- M.Ç., S.G.Ç., M.D., M.C.A.; Design - M.Ç., S.G.Ç., M.D., M.C.A.; Data Collection or Processing - M.Ç., S.G.C.., M.D., M.C.A.; Analysis or Interpretation - M.Ç., S.G.C.., M.D., M.C.A.; Literature Search M.Ç., S.G.Ç., M.D., M.C.A.; Writing - M.Ç., S.G.Ç.

Conflict of Interest: No conflict of interest was declared by the authors.

Financial Disclosure: This study was approved and funded by the School of Medicine Animal Care and Investigational Committee at our institution. The funders had no role in study design, data collection, and analysis, decision to publish, or preparation of the manuscript.

\section{References}

1. Luo X, Barbieri D, Davison N, Yan Y, de Bruijn JD, Yuan H. Zinc in calcium phosphate mediates bone induction: in vitro and in vivo model. Acta Biomater 2014; 10: 477-85.

2. Hadley KB, Newman SM, Hunt JR. Dietary zinc reduces osteoclast resorption activities and increases markers of osteoblast differentiation, matrix maturation, and mineralization in the long bones of growing rats. J Nutr Biochem 2010; 21: 297-303.

3. Yamaguchi M. Role of nutritional zinc in the prevention of osteoporosis. Mol Cell Biochem 2010 May; 338: 241-54.

4. Brzóska MM, Rogalska J. Protective effect of zinc supplementation against cadmium-induced oxidative stress and the RANK/RANKL/OPG system imbalance in the bone tissue of rats. Toxicol Appl Pharmacol 2013 1; 272 : 208-20

5. Leary S., Underwood W., Anthony R., Cartner S., Corey D., Grandin T., et al. AVMA Guidelines for the Euthanasia of Animals, 2013 ed. Schaumburg, IL, USA: American Veterinary Medical Association; 2013. pp.1.102

6. Baltaci SB, Mogulkoc R, Baltaci A, Emsen A, Artac H. The effect of zinc and melatonin supplementation on immunity parameters in breast cancer induced by DMBA in rats. Arch of physiol biochem 2018; 124: 247-52.

7. Chrysou K., Halat G., Hoksch B., Schmid RA., Kocher G. J. Lessons from a large trauma center: impact of blunt chest trauma in polytrauma patients-still a relevant problem Scand J Trauma Resusc Emerg Med 2017; 25: 42.

8. Tulay CM, Yaldiz S, Bilge A. Do we really know the duration of pain after rib fracture?. Kardiochir Torakochirurgia Pol 2018; 15: 147-50.

9. Farzanegan R, Feizabadi M, Ghorbani F, Movassaghi M, Vaziri E, Zangi M, et al. An overview of tracheal stenosis research trends and hot topics. Arch Iran Med 2017; 20: 598-607.

10. Chien CY, Chen Y-H, Han S-T, Blaney GN, Huang T-S, Chen K-F. The number of displaced rib fractures is more predictive for complications in chest trauma patients. Scand J Trauma Resusc Emerg Med 2017; 25: 19.

11. Whitson BA, McGonigal MD, Anderson CP, Dries DJ. Increasing numbers of rib fractures do not worsen outcome: an analysis of the national trauma data bank. Am Surg 2013; 79: 140-50.

12. Jones KM, Reed RL, Luchette FA. The ribs or not the ribs: which influences mortality? Am J Surg 2011; 202: 598-604.

13. Takikawa S, Matsui N, Kokubu T, Tsunoda M, Fujioka H, Mizuno K, et al. Lowintensity pulsed ultrasound initiates bone healing in rat nonunion fracture model. J Ultrasound Med 2001; 20: 197-205.

14. Easter A. Management of patients with multiple rib fractures. Am J Crit Care 2001; 10: 320-7; quiz 328-9.

15. Yusa K, Yamamoto O, Fukuda M, Koyota S, Koizumi Y, Sugiyama T. In vitro prominent bone regeneration by release zinc ion from Zn-modified implant. Biochem Biophys Res Commun 2011; 412: 273-8.

16. Santana-Rodríguez N, Clavo B, Fernández-Pérez L, Rivero JC, Travieso MM, Fiuza MD, et al. Pulsed ultrasounds accelerate healing of rib fractures in an experimental animal model: an effective new thoracic therapy? J Thorac Cardiovasc Surg 2011; 141: 1253-8.

17. Calik M, Aribas OK, Kanat F. The effect of costal cartilage resection on the chest wall development: a morphometric evaluation. Eur J Cardiothorac Surg. 2007; 32: 756-60. 